\title{
Supervision of Academic Supervisor and Quality of Education in Madrasah Ibtidaiyah
}

\author{
Nur Hasanah \\ IAIN (State Islamic Institute) Salatiga \\ nurhasanah201157@yahoo.com
}

\begin{abstract}
Supervisors are one of the most important elements in ensuring the quality of madrasah education. Therefore, the duty of the supervisor have to be in accordance with the work program about the quality of education in the madrasah is in accordance with the standards set by the madrasah. The maximum implementation of supervisory to the academic supervision will help the quality of madrasah education to be achieved. This study aims to determine the academic supervisory competence of madrasah supervisors, the quality of madarasah education, and the relation of academic supervisory competence and the quality of Madrasah Ibtidaiyah education in the Sub-district of West Ungaran Barat, Semarang District.

This study used the method of observation, interviews, and documentation. And the data analysis used flow flows. The conclusion of this study was that the academic supervision competence of the Madrasah Ibtidaiyah supervisor has been carried out but has not been maximally in accordance with the supervisor's work program. While, the education quality of MI Nyatnyono 2 and MI Lerep in the process standards and results have not been maximized. And the relations of the supervisors' academic competency supervision and MI (Madrasah Ibtidaiyah) quality education are associative relations in the form of cooperation, accommodation and supervisory associations in conducting academic supervision in the MI so that the quality of MI education in standard processes and results can be carried out even though it is not maximized.
\end{abstract}

Keywords: Supervision of the Academic Supervisors, Quality of Education, Madrasah Ibtidaiyah 


\section{INTRODUCTION}

Supervisors are one of the elements of education stakeholders who are considered urgent in determining the quality of education (Yuguda \& Bin, 2015). There were two tasks that must be carried out by the madrasah supervisor, namely the task of academic supervision and managerial supervision in the madrasah which was appointed through the supervisory duties and functions, namely the activities of monitoring, evaluating, fostering, reporting and following up.-. It was as stated in the Decision of the Ministry of Administrative Reform (Kep. MENPAN) Number 118 of 1996 that madrasah supervisors are civil servant (ASN (PNS)) who given full duty, responsibility and authority by officials who are authorized to supervise education in madrasah by carrying out assessments and guidance from technical education and education administration in education units (Kep. MENPAN Number 118 of 1996).

Based on Kep. MENPAN the task of the madrasah supervisors is to be able to provide alternative solutions to problems in learning. In this case the supervisor helps the headmaster and teacher understanding the problem of education and being able to solve the problem wisely which ultimately can bring changes to the quality of student education -. Thus the supervisor possesses a very strategic role in improving the quality of education in the madrasah Ibtidaiyah with the carried out tasks namely guiding, fostering, monitoring supervision, evaluating, making reports and following up on the results of supervision. 
Additionally supervisors are also contributing to the quality assurance process at the madrasah education guidance -. In order - to improve his professional competence in carrying out his duties to the fullest. Madrasah is one of the educational institutions under the Ministry of Religion, and has undergone various changes and well developments following the development of the globalization of the Indonesian nation (Rahim, 2004: 23).

Madrasah education aims to equip students who can integrate the knowledge and faith and piety that have been expected by the community. It was the vision and mission of the madrasah that are Islamic, populist, and quality.

In reality, madrasah education was still a low quality standard especially for private madrassah. The conditions of the education staff, students and educational stakeholders are still far from the quality standards and quantities needed, especially in religious mastery that is still lacking and not professional.

Madrasah Ibtidaiyah (MI) in the sub-district of West Ungaran Barat is a private madrasah which seen from the quality of its educators accordance with their expertise generally. From the achievement, it was still lacking on teaching system. It showed that MI is still lacking in education quality, even though the existence of the madrasah since its establishment until now is around 30 years old. The question was why the quality of education of the madrasah in the subdistrict of West Ungaran had a weakness, how the duties and 
responsibilities of supervisors reached for their guided madrasah, and the madrasah supervisors in carrying out their duties in accordance with their competencies.

This study focused on academic supervision competencies, where the competency was one of the abilities of the madrasah supervisor in the duties of academic supervision. It was called coaching and evaluating teachers to improve the quality of learning. Then, the main goal of academic supervision was the teacher in the learning process. The main materials in the learning process were (syllabus and Learning Implementation Plan, selection of strategies/methods/learning techniques, use of media and information technology in learning, assessment of process and learning outcomes).

Based on problem, the focus of this research were such as: the supervisory competence of Madrasah Ibtidaiyah academic supervisors in the sub-district of West Ungaran, Semarang District; the quality of education of Madrasah Ibtidaiyah in the sub-district of West Ungaran, Semarang District and; the relation of the supervisory competence of the academic supervision and quality of education of madrasah Ibtidaiyah in the sub-district of West Ungaran, Semarang District?

\section{METHODS}

This study used descriptive qualitative approach. It was done by collecting data in the form of words and the results of observations and personal 
records (Moleong, 2002: 11)-. The main of this research was to reveal the various problems related to the supervisory competence of academic supervisor and the education quality of Madrasah Ibtidaiyah. The subjects of the study are MI Supervisors, Madrasah Headmasters, and MI teachers of sub-district of West Ungaran.

Whereas, the method of the research used interactive and noninteractive method (Comte, 1984: 14). The research methods were: interviews; observations; and documentation. The validity test in this research used triangulation analysis. Triangulation was goten by comparing data observation from various respondents who related to the supervisory competence of academic supervisors and quality of education of Madrasah Ibtidaiyah with the results of the interviews-; comparing the data of the informants in general with the data obtained personally from research subjects, both from the center of information sources and other related sources of information; comparing the interview results with notes in the document -Supervision of academic supervisors and the quality of MI education. Analysis of the data used descriptive exploratory analysis. The flow used in the interpretation of data in this study was the theory found by Miles, Huberman (1992: 16), namely data reduction, data presentation, and verification. 


\section{DISCUSSION}

Assessment of supervisory competence of academic supervisors and the quality of MI education in the Sub-district of West Ungaran in this research was carried out by - this was done by the headmaster and teachers of the class IV and V. This was done to respond how supervision has been carried out by inspectors over the years, and how the quality of education of guided madrasah, and how the relation of supervisor's competence with the quality of the madrasah education.

\section{Supervisory Competence of Academic Supervisors}

The supervisory competencies of academic supervisors in this study include three aspects Planning-learning; Actuating-learning; and Evaluating-learning. These three aspects could be broken down into several indicators as follows: mastery of theories, concepts, characteristics and principles of changing tendencies in each subject; guidance for teachers in the preparation of subject syllabus based on content standards, Competency Standard (SK) and Basic Competencies (KD) and the principles of K.13 development; carry out guidance to the teacher in determining and using learning methods and techniques in each subject; conduct guidance on teachers in preparation of lesson plan (RPP) in each subject; carry out guidance on teachers in learning practice in the laboratory and outside the classroom; carry out guidance to the teacher in the management, care, development and the use of learning media; and conducted a guidance on teachers in the use of information technology 
(IT) for learning; caried out guidance to the teacher in preparing learning evaluations.

In the implementation of academic supervision, a supervisor must had competence in coaching, directing, guiding teachers so that they could meet the class professionally, guiding and directing students with noble and noble character, having the results of work and positive changes in the learning process, can make learning having more meaning. Because of teachers were important position in determining success in learning. Therefore, supervisors could expand and develop their abilities in their place of duty to carry out supervisory duties such as implementing learning, reporting learning administration, -oversight such as teaching, administration, and emotional support.

The support from the supervisor for the supervisee wouldgive a sense of security and remove fears and guilt they experienced. In this case, the supervisor had to take the time to provide an explanation of the similar perceptions and the correct view point between theory and practice. Supervisors had to be able to position themselves as smart parents and understand the different characteristics of teacher abilities with applicable regulations.

Supervisory competence in aspects of planning of learning which includes: guidance-teacher in preparing syllabus and guidance-teacher in making Learning Implementation Planning (RPP). The headmaster of the madrasah and the teacher assessing the supervisory competence of 
academic supervisor in aspects of learning planning is good because of the two indicators that have been implemented all by supervisors.

Even though the implementation was not in accordance with the supervisor's work program, where the supervisor conducts guidance in aspects of learning planning only one time in one semester and it is carried out in teacher meetings at the KKM (Madrasah Working Group) and KKG (Teacher Working Group).This is due to the ratio of the number of supervisors to the imbalance of the number of teachers in the madrasah, one supervisor fostering madrasah teachers in 3 sub-districts with 1 sub-district consisting of 7 madrasah, thus one supervisor fostering 21 madrasah. Besides that there are still other duties from supervisors who must attend seminar, workshops and supervisory training.

Supervisory competence in the implementation of learning includes: 1) guidance the teacher in using learning method, 2) guidance the teacher in using learning media, 3) guidance teachers in utilizing IT. The headmaster of the madrasah and the teacher in assessing the supervisory competence of academic supervisor is good, even though in its implementation it has not been in accordance with the technique and the time in the supervisor's work program was determined. Where, the supervisor monitors the madrasah one semester only once, even though academic supervision must be carried out continuously and continuously. This is because the number of teacher per-guided madrasah still multiplied by the number of guided madrasah which is far from the real ideal ratio. Moreover, the location of the madrasah which is located far 
from one another is even difficult to reach by transportation. Teacher guidance in the implementation of this learning is carried out by the supervisor in a classical manner on teacher meetings, it was called KKG and KKM, which should be done by way of visits to schools/madrasah which in this case are techniques of academic supervision individually.

Academic supervision competencies of supervisors in learning evaluation include: 1) aspects of guiding teachers to make assessment instruments, 2) guiding teachers to carry out assessments. The madrasah head's assessment and the teacher's supervisory competence in guiding the teacher make good instrument assessment of learning, because the learning assessment is made by the teacher in the lesson plan and has been implemented for weekly, monthly and for each semester.

Academic supervision of supervisors were carried out in groups through teacher meeting. Even though, teacher guidance in relation to academic supervision would result in maximum results if it is implemented individually. The statement wrote by Ardiansyah (2009: 21) who said that the individual supervision technique was carried out by the supervisor of a teacher who has a problem or has a particular case. So that, the implementation was done by face to face between supervisors and the teachers. Supervision technique was categorized as individual techniques include: classroom monitoring, observation of classroom learning, personal meetings, inter-class monitoring, and evaluation, and self-assessment. 
Besides the techniques that must be used by supervisors in academic supervision, there are several principles that must be held in academic supervision as follows: 1) Harmonious. This means that supervision can establish a relationship in a peer, humanist, friendly and informal. This happens both between supervisors and with various other parties involved with the supervision program. For this reason, supervisors must have various attitudes, such as being friendly, humorous, cheerful, consistent, honest, helpful, understanding, patient, and attentive; 2) Continuity. Supervision was carried out continuously. Because of academic supervision was one of the main functions of all school programs.

The success of a supervisor is not seen from the effort of selfdevelopment that has been carried out by the supervisor alone but needs to be carried out on an ongoing basis. Because the problem of the learning process at any time appears in accordance with the times; 3 ) Democratic. It meant, the implementation of academic supervision should not be dominated by supervisors. Academic supervision emphasizes the activities and cooperation of supervisors. The trained teacher must be actively involved. The teacher is also responsible for the improvement, not just the supervisor. For that supervisors, they must plan, develop and implement joint supervision programs with principals, teachers, and various parties involved in academic supervision under the coordinator supervisor; 4) Integral to education programs. This means that education is as a system in which there are several systems, organized and work together to achieve 
educational goals. The system includes administrative behavior, academic behavior, student behavior, counseling development behavior, academic supervision behavior. Each system is an integral unit. Therefore the academic supervision program is integral to the overall education program. To realize the system requires good and harmonious relations both supervisors and all parties as implementers of educational programs; and 5) Comprehensive. This means that the aspects contained in the overall academic supervision program are developed based on analysis of previous academic development needs.

It was done in an effort to meet the various demands of the purpose of educational supervision which includes increased professionalism, quality coaching, and teacher motivation; Constructive. This means that academic supervision is done to correct deficiencies in teacher performance. So that it can be seen how far the development of teacher creativity in its performance. Thus the teacher can understand the academic problems he faces the teacher and is able to solve them; 7) Objective. This means that the academic supervision program must be evaluated objectively. Where in the assessment of academic supervision programs are arranged based on the real needs of professional teacher development. Likewise in evaluating the success of the academic supervision program. This is the most important factor in the assessment of academic supervision requiring instruments that have high validity and reliability to measure the extent of teacher competence in managing learning (Siahan, 2006: 18-20) 
The Quality of Madrasah Education

The scope of quality education covers education inputs, processes and outputs. The quality of education is the ability of the education system to prepare, and process education effectively and efficiently to increase added value to produce quality output. Output generated by education - quality should also be able to meet the needs of stakeholders.

The quality education could be showed by the institution's ability to meet customer needs according to applicable quality standards (Mulyasa (2003: 226; Yamtim \& Wongwanich, 2014: 2998). The intended user is the user within the institution itself and the user outside the institution/general public). So, the quality of education is not only a concept that is separated from internal users but there is a correlation with the demands and needs of the community. Where, the conditions of the people are innovative and experience rapid progress in accordance with the times.

So that, the educators must be able to be a counterweight to the occurrence of innovation that was fast and able to produce products in accordance with the needs of the community. To find out the quality of education in madrasah, the government had made educational quality standard guidelines issued by the Education National Standard Board (BNSP) as contained in the government regulation (PP) number. 19, 2005, which include: contents standard, standardized processes, infrastructure standards, graduation competency standards, human 
resources management competency standards, financing management standard, assessment/results competency standards. But in this paper, it emphasizes the context of process standards and results standards, with the reason for adjusting the theme in this paper is academic supervision.

The quality of education of Madrasah Ibtidaiyah in the Subdistrict of West Ungaran viewed from standard process and outcome indicators include the teachers to create lesson plans, using media and learning methods as well as making and carried out by an already good assessment not maximized. It could be understood by the observation of teachers teaching in class that in the majority of the samples were made respondents in the MI Nyatnyono 2 dan MI Lerep as some indicators: 1) The majority of MI Nyatnyono 2 and MI Lerep teachers have made/compiled a lesson plan in accordance with the subjects they were teaching, even though they were not on time; 2) Most of the teachers had not synchronized the subject matter in learning method applied. It could be seen, when, the teacher tend to use the lecturing method only; 3) The teachers teached with provided facilities; 4) The majority of teachers had compiled and implemented learning evaluations both daily, weekly and sub-summative evaluations.

The other aspect were 1) Human resources (HR) from - the pedagogical and professional competence was low. So, the learning method was monotonous and boring because it was not modified; 2) The unavailability of learning facilities such as multi-media classes, laptop, LCD, practicum rooms that are suitable for the needs of teachers in the 
madrasah; 3) Management of learning facilities did not conducive such as classrooms that are not soundproof, classrooms that are less standard so that the learning environment is less comfortable; 4) Community existence in the environment industries that are more individualistic (prioritizing work than education) hard to be invited to collaborate in giving input, or opinions in an effort to improve the quality of madrasah education.

By the competence of graduates student achievement, there were some students could be recognized into the education level above in SMP N (State Junior Hish School) or MTs N (State Madrasah Tsanawiyah). The data was obtained by interviews with the head of the madrasah Ibtidaiyah nyaatnyono 2 Sendang Rejo and MI Lerep are students from two MI who were sampled in this study that in 2017 MI Nyatnyono 2 Sendang Rejo students who were accepted in SMP N there were 9 students from the total of 25 students, while the MI Lerep in 2017 students who were admitted to SMP $\mathrm{N}$ were 6 students out of a total of 23 students. In such a way the education quality of Ungaran Subdistrict MI at the standard results is still low because the percentage is below $50 \%$ of which students perform well. Departing from the quality of education in MI West Ungaran Sub-District which is still low, the madrasah paid attention to the principles that must be held in an effort to develop the quality of education by looking at several influential factors in it. 
Relationship between Supervisor Competences and Quality of Education in Madrasah Ibtidaiyah

The definition of relation was a community of people who occupied certain areas and interact and get to know each other in the human group (Hidayati, 2014: 1). Relationships in social relations is a reciprocal relationship between individuals influence each other. The various stages of social relations, called by (a) Zero contact, a condition where there is no relationship between two people; (b) awareness that is someone has begun to realize the presence of others; (c) surface contact, namely the first person is aware of the same activity by someone around him; and (d) mutuality, namely the interaction between 2 people.

The purpose of social relations in this paper is the relationship between the supervisor and the head of the madrasah and teachers between personal with personal, personal with groups, and groups with groups. Relations or social relations in the supervision of academic supervisors with the head of the madrasah and with the teachers of the madrasah Ibtidaiyah in West Ungaran Sub-district is an associative relationship which includes cooperation, accommodation and assimilation. In the form of cooperation, it can be done in mentoring, namely guiding teachers to compile programs, promissory notes, and lesson plan. Then in the form of accommodation can be done in monitoring the teacher in the use of methods, learning media, and making evaluations of learning in the classroom and assessing teacher learning in the classroom. And in the form of assimilation, it can be seen in the 
follow-up as a supervision report that has been carried out by the supervisor by providing guidance to teachers whose performance is not in accordance with the objectives specified in the supervisor's academic supervision. This associative relationships as Hidayati theory (2014: 1), which states that the social relations between individuals as well as individuals and groups in a long time and to achieve the same goal. Thus, it can be seen that the relationship between supervisors and madrasah principals and Madrasah Ibtidaiyah Nyatnyono 2 teachers and Lerep Madrasah Ibtidaiyah both teachers and supervisors, and supervisors with Madrasah Ibtidaiyah institutions in academic supervision in MI are guided, the aim is the same, namely the aim of advancing and improving the quality of Madrasah Ibtidaiyah education. Supervisors and teachers create this associative relationship in visiting madrasah activities to assess teacher learning activities in classrooms and teacher meetings in KKG and KKM activities.

\section{CONCLUSION}

Based on the research of the supervisory competence of supervisor and quality education of Madrasah Ibtidaiyah in relation competence in West Ungaran Sub-district, it could be concluded that academic supervision competence had been carried out in accordance by the duties and functions of academic supervision which include learning planning, implementation of learning, evaluation of learning, assessment of teacher activities in learning, making academic supervision reports and making 
follow-up on academic supervision results, but not maximally; the quality of education Madrasah Ibtidaiyah in West Ungaran Sub-district was standard competencies by the capability of teachers to prepare the lesson plans, the use of learning methods, the use of learning media and the preparation of assessments have been carried out but have not been maximized.

The relation of supervision of academic supervisor and education quality of Madrasah Ibtidaiyah was an associative social relation in the form of: Cooperation which includes supervisory activities fostering, monitoring teachers in learning planning; accommodation which includes supervisor activities assesses the teacher in the implementation of learning; and ssimilation which includes the activities of the supervisor follows up on reports from academic supervision.

\section{REFERENCES}

Ardiansyah, Asrori. (2009). Educational Supervision Engineering (Teknik Supervisi Pendidikan. Malang: UIN Malang.

Astuti, S. (2012). Pattern of Social Relations with Farmer Workers in Agricultural Production. Thesis (Pola Relasi Sosial dengan Buruh Tani dalam Produksi Pertania. Skripsi), Medan: University of North Sumatra.

Goetz, Comte. (1984). Qualitative Research for Education, Boston: Allyn and Bacon .Inc.

Hidayati, DS. (2014). Increased Social Relationship Through Therapeutic 
Mudarrisa: Jurnal Kajian Pendidikan Islam, Vol. 11, No. 1, 2019

Social Skills in Schizophenia Katatonik Patients (Peningkatan Relasi Sosial Melalui Sosial Skill Terapy pada Penderita Schizophenia Katatonik), Online Journal of Psychology, 2 (1), Faculty of Psychology, University of Muhamadiyah Malang.

Hosnan. (2016). Professional Ethics of Educators: Fostering and Strengthening the Performance of Principal Teachers, and School Supervisors (Etika Profesi Pendidik: Pembinaan dan Pemantapan Kinerja Guru Kepala Sekolah, serta Pengawas Sekolah), Jakarta: Ghalia Indonsia.

Huberman, Miles. (1992). Qualitative Data Analysis: Resource Book about New Methods, Happen. Tjejep Rohandi, Jakarta UI Press.

Jeromi S., Arcaro. (2006). Quality Based Education; Principles of Formulation and Procedure for Implementation (Pendidikan Berbasis Mutu; Prinsipprinsip Perumusan dan Tata Langkah Penerapan), Yogyakarta: Student Library

Decision of the Ministry of Administrative Reform (Kep. MENPAN) Number 18 of 1996 concerning the Functional Position of School Supervisors and their Figures (Jabatan Fungsional Pengawas Sekolah dan Angka Kriditnya), Jakarta: Ministry of National Education.

Moleong J. Lexy. (2009). Qualitative Research Methodology, Bandung Remaja Rosdakarya.

Mulyasa. (2003). Becomes Professional School Principal in the Context of 
Mudarrisa: Jurnal Kajian Pendidikan Islam, Vol. 11, No. 1, 2019

Successful SBM and KBK (Menjadi Kepala Sekolah Profesional Dalam Konteks Mensukseskan MBS dan KBK), Bandung: Youth Rosda Karya.

Republic of Indonesia Government Regulation Number 19 of 2005 concerning National Education Standards.

Sallis, Edward. (1993). Total Quality Management in Education, Yogyakarta.

Purwanto, Ngalim. (2003). Educational Administration and Supervision (Administrasi dan Supervisi Pendidikan). Bandung: Rosdakarya.

Sudjana, Nana. (2009). School Supervisor Competency (Kompetensi Pengawas Sekolah). Jakarta: Bimantara Publishing.

Rahim, Husni. (2004). Anatomy of Madrasas in Indonesia (Anatomi Madrasah di Indonesia), Jakarta.

Siahaan, Amirudin. (2006). Education Supervisory Management (Manajemen Pengawas Pendidikan). Jakarta: Quantum Teaching. 